\title{
The impact of ownership on building sustainable and responsible businesses
}

\section{BELÉN VILLALONGA}

Abstract: This article reviews what we know and do not know about the impact of ownership on building sustainable and responsible businesses. It begins by analysing why firm owners are an important driver of responsible business behaviour, and reviews whether such behaviour comes at a financial cost to owners or not. It then discusses how owners drive responsible business behaviour as compared to other stakeholders, reviewing the empirical evidence about the impact of different owner types on various forms of responsible business.

My review shows that there is a fair amount of research about certain topics, such as the relation betweeen financial and social performance and about the social and enviromental impact behaviour of the two most prevalent types of owners of public corporations - families and institutional investors - although the cumulative evidence on those topics is far from conclusive. Moreover, there are also a number of gaps in our knowledge that warrant further research to inform recommendations to business leaders and policy makers. These include the relative effectiveness of different types of owners, stakeholders, and organisational forms at building sustainable and responsible businesses; the impact of the recent evolution of capital markets on CSR behaviour; and the social snd enviromental impact of the state, foundations, and employees as owners of corporations.

Keywords: Ownership, sustainability, responsibility, social, environmental, performance, family firms, institutional investors.

\section{EXECUTIVE SUMMARY}

Equity ownership of corporations is a critical factor in building sustainable and responsible businesses. The paper sets out to review previous studies of this relationship and adopts a multidisciplinary approach to identify gaps in the understanding of how ownership has an impact on business practices and policies. 
Given the sharp decrease in the number of public corporations in certain equity markets in the last two decades, the relationship between the environmental and social activity of different types of organisations, and their financial performance is an important focus. The author notes that the corporate form is properly the choice of the equity owners, who also choose how to manifest their environmental or social concerns through their investment and management processes.

Early studies of the relationship and correlation between better environmental, social, and governance practices and financial performance show mixed results, but later studies indicate a positive relationship, particularly over the long run. Equity owners supporting a sustainable business model may agree to transfer value from shareholders (themselves) to other stakeholders, but it is not clear whether that represents net value creation, or a trade-off between financial and non-financial performance.

The sheer perception of a trade-off may deter investors from engaging in, let alone driving, sustainable business practices, but some studies demonstrate that the trust built by investing in social capital is particularly valuable when the overall level of trust in corporations and markets suffers a negative shock, and that CSR (corporate social responsibility) is positively related to firm value over the long run.

Other motivations may bolster an impression of corporate social responsibility, without underlying substance, and provide an effective entrenchment strategy for inefficient CEOs. Managerial engagement in responsible business practice has also been decried as a form of agency behaviour, enhancing personal reputation at the expense of shareholders.

The author notes that no research to date has examined the relations between financial returns to shareholders and taxes paid as a form of social contribution, nor the trade-off that might exist between taxes paid and direct investments in CSR practices.

From purely incremental steps to radical business transformations, the research explores ways corporations can build sustainable and responsible businesses. It is important to recognise the range of approaches, since there is likely to be a mutual dependency between the range and business ownership.

Different corporate forms do appear to create different types of social value. There is plenty of literature on cooperatives and social enterprises, but little information comparing their social performance to other organisations.

Family owners, for example, target profit maximisation but also tend to protect their 'socio-emotional' wealth, despite limited resources. Many have significant philanthropic activities, which prioritise social purpose even at net cost.

Institutional investors have a range of passive to active strategies from positive and negative screening to fully engaged impact investing, but which stakeholders bear the costs and benefits of these is still not clear. 
Ownership by the same institutional investor across firms that are horizontally or vertically related make socially responsible behaviour more likely and effective, but they depend on other highly variable factors, such as competitive advantage, activist engagement, and customer awareness.

The paper also notes the role of stakeholders, including employees, customers, suppliers, local communities, the government, or proxy advisors, in building responsible businesses. The question remains as to which is most effective at transforming the ecosystem. Some research indicates that internal managers are often the ones to initiate CSR practices, while activist investors have an increasingly powerful voice.

Overall, much more research is needed into the long-term impact of different types of investors, the trade-off between long-term benefits and short-term costs for shareholders and stakeholders. Better data, longer time series, and better research methodologies may help address causality and identification issues.

\section{INTRODUCTION}

What impact does ownership have on building sustainable and responsible businesses?

The first challenge in summarising what we know and do not know about this question is the lack of a uniform definition of what is meant by 'sustainable and responsible business.' This lack of uniformity and the proliferation of a variety of terms and acronyms to refer to similar concepts partly reflects the multiple ways in which firms can contribute to society and have a neutral or positive impact on the environment. It also partly reflects the multidisciplinary nature of the subject. ${ }^{1}$

In corporate circles (and in the management literature), for instance, the most frequently used term is 'corporate social responsibility' (CSR), although 'sustainability' is increasingly being used. Faller and zu Knyphausen-Aufseß (2018) note that the latter term arose from a predominantly environmental perspective, but both terms are increasingly being used interchangeably to suggest the integration of environmental and social objectives with firms' traditional economic or financial objectives in firms' strategic and operational decisions - what is often referred to as the 'triple bottom line'. In contrast, terms like 'environmental, social, and governance' (ESG) and

\footnotetext{
${ }^{1}$ Both the subject of corporate ownership and the subject of corporate social responsibility (CSR) are interdisciplinary in nature. Accordingly, they have received the attention of multiple academic fieldsmanagement, finance, accounting, law, and economics. However, much of this research is published in second-tier and specialised field journals, a fact that does not necessarily speak to the quality of the studies as much as about the fact that these topics have only entered the mainstream of these fields relatively recently - if at all. Accordingly, my review of the literature is agnostic about the field or journals in which the research is published, if not about the rigour of the studies themselves.
} 
'socially responsible investment' (SRI) are more commonly used in financial circles, both practical and academic. Clark and Viehs (2014) distinguish between the two main terms, CSR and ESG, as follows: 'CSR embraces all corporate behaviours and organisational processes which directly or indirectly affect the corporation's stakeholders.' In contrast, the term ESG summarises the extra-financial information on a corporation's environmental (E) and social (S) behaviour as well as its governance (G) structures, which, they argue, can be used to assess corporations regarding CSR (an implicit assumption in most of the ESG literature). In most of this paper I use the term CSR given its higher prevalence and the fact that the governance $(G)$ part of ESG constitutes a more indirect and questionable measure of responsible and sustainable business practices. Nevertheless, when reviewing the findings of studies that focus on ESG measures of CSR, I maintain the ESG term they use.

The review is structured as follows. First, by way of motivation, the chapter begins by analysing the reasons why firm owners are an important driver of responsible business behaviour. One reason that suggests owners may in fact be a more important driver than any other stakeholder is the generalised belief that responsible business behaviour may come at the expense of the financial returns to the capital that owners need to provide for any business to exist. To assess whether this belief is indeed substantiated by empirical evidence, a separate section of the paper is devoted to reviewing the extensive literature about the relation between a company's social performance and its financial performance - and finds highly mixed results.

The third section addressess the central research question in this chapter-how owners build sustainable and responsible business. The section begins by reviewing the variety of ways in which different owners can drive responsible business practices. The role of shareholders in driving such practices is then compared to the roles of other stakeholders - a comparison on which the evidence proves to be quite limited.

The fourth section follows by reviewing the empirical evidence about the impact of different owner types on various forms of responsible business. A thorough review of this literature shows that there is a fair amount of research about the behaviour of two most prevalent types of owners of public corporations - families and institutional investors - but that it is very hard to draw solid conclusions from it given the disparity of findings. The review also uncovers a dearth of rigorous research about the social and environmental impact of other business owners.

To conclude, the most salient gaps in our knowledge about the role of ownership in building sustainable and responsible business are distilled from the preceding review. 


\section{WHY DOES OWNERSHIP MATTER FOR BUILDING SUSTAINABLE AND RESPONSIBLE BUSINESSES?}

Different firm owners have different preferences and objectives with respect to the companies whose equity they hold. ${ }^{2}$ They may have different investment horizons for themselves and therefore favour longer or shorter term investments at these firms, ranging from months for the average mutual fund in the New York Stock Exchange or a few years for private equity investors, to decades or even centuries for family firms. They may have different risk exposures based on their degree of diversification - for instance, founders and their families often have most, if not all, of their wealth concentrated in their business, and therefore a much higher exposure to idiosyncratic risk than a mutual fund. They may have different goals - for instance, institutional investors typically seek to maximise financial returns on behalf of their own investors, families often seek to maximise their socioemotional wealth, and governments (hopefully) seek to improve social welfare for their citizens. ${ }^{3}$

There is also significant heterogeneity in goals, preferences, and time horizons within owner types. (See, e.g., Bushee (1998, 2004) and Hoskisson et al. (2017) about differences across institutional investors; Bacon et al. (2013) about differences across

\footnotetext{
${ }^{2}$ This paper uses the term 'owner' somewhat loosely to refer to those owners of equity in corporations (or their equivalent in other legal forms of business organisation) who exercise decision-making rights over the company's strategy, either directly (for example, at shareholders' meetings) or through a governance body like a board of directors. A few clarifications are perhaps in order. First, as Stout has repeatedly pointed out throughout her work (e.g., Stout 2007, 2012), shareholders do not own the corporation. Rather, what they own (or in some cases, even just hold temporarily) is a type of security commonly called stock, and that difference in the object of property carries with it important legal implications. This paper nevertheless uses the term 'firm owners' or 'corporate owners', as is common practice, for simplicity and generality, since this paper seeks to cover various business organisation forms, not just corporations.

Second, as documented in a large number of empirical studies of the ownership of public corporations around the world, shareholders often hold their shares indirectly through a variety of investment vehicles (e.g., Claessens et al. 2000, Faccio \& Lang, 2002, La Porta et al. 1999, Villalonga \& Amit, 2009). Examples of such investment vehicles are trusts, foundations, limited partnerships, and other public or private corporations, which are often set up by founders or their families for reasons of control enhancement, tax and estate planning, philanthropy, or liability protection, among others. In cases like these, what is meant by 'owners' in this paper, as in the corporate ownership literature, are not the investment vehicles but the individuals and families behind them. On the other hand, when the direct owners of shares are investment funds, such as mutual funds, pension funds, private equity funds, or hedge funds, it is the institutions that manage those funds (for example, Blackrock, Blackstone), and not the retail investors who buy shares in those funds, that I treat as the shareholders of interest-again, consistently with all the finance and corporate governance academic literature.

${ }^{3}$ Socio-emotional wealth is the catch-all term coined by Gómez-Mejía et al. (2007) to capture all the non-financial assets that business families typically seek to protect, such as the family's unity, harmony, reputation, legacy, or political influence.
} 
private equity investors; or Villalonga (2009) and Miller et al. (2015) about differences across family firms.)

Moreover, owners have the right — and the responsibility - to shape strategy in the firms they own, whether it is through their participation in, representation on, or engagement with the firm's board or top management team, or by submitting shareholder proposals and/or voting at annual shareholder meetings. This fact is often overlooked in the academic literature, which tends to portray CEOs as the sole individual responsible for strategic decision-making, assuming that companies are widely held by a dispersed group of passive shareholders. However, a growing volume of research has shown that such a model of business organisation is in fact more the exception than the norm around the world, even in the United States (Holderness 2009, Kahan \& Rock 2008, Villalonga \& Amit 2009), and increasingly so: the number of US public corporations has almost halved over the last twenty years-from over 8,000 in 1996 to about 4,300 in 2016. ${ }^{4}$ Mayer (2013) and Franks and Mayer (2017) document a similar phenomenon in the United Kingdom.

The reality is that most companies around the world - including public corporations - have one or more large shareholders who actively exercise control or significant influence over their company's strategy (Claessens et al. 2000, Faccio \& Lang 2002, La Porta et al. 1999, Villalonga \& Amit 2006, etc.). These shareholders include founders and their families, the state, private equity firms, activist investors like hedge funds, other institutional investors, industrial foundations, and employees acting in concert.

Therefore, owners are likely to be a key driver-if not the primary one-behind their firms' responsible behaviour, or lack thereof. They may not be the only driver, though; other stakeholders such as employees, customers, or suppliers may also be, and have preferences and agendas of their own. The extent to which owners are able to implement their preferences and shape their firms' strategies thus depends on their relative power vis-à-vis other stakeholders and shareholders in the same firm-which in turn partly depends on the extent to which they can control or have significant influence over the firm through their equity ownership, voting power, board control, or participation in management.

\footnotetext{
${ }^{4}$ Doidge et al. (2017) show that the decline is attributable to a combination of factors: 54 per cent is due to a reduction in the number of initial public offerings (IPOs), as documented by Gao et al. (2013), while the remaining 46 per cent is due to an increase in the number of delistings. The latter, in turn, are attributable to two different trends: (1) an increase in mergers and acquisitions (M\&A) activity, with resulting increases in market concentration (Grullón et al. 2017); and (2) companies going private due to regulatory changes like the Sarbanes-Oxley Act that have altered the cost-benefit analysis of being public versus being private (Engel et al. 2007).
} 


\section{FINANCIAL RETURNS TO OWNERS OF SUSTAINABLE BUSINESSES}

In addition to the reasons given above, owners are a particularly important driver of responsible business behaviour relative to other stakeholders to the extent that such behaviour may come at the expense of the financial returns on the capital they provided to the business. In other words, making a business more sustainable may result in a transfer of value from shareholders to other stakeholders, and shareholders hold the key to that transfer. Whether there is in fact such a sheer value transfer as opposed to net value creation in the aggregate - that is, whether there is or not a trade-off between financial and non-financial performance- - has been the subject of considerable debate in both research and practice.

There have been literally hundreds of studies about the relation between a company's social performance and its financial performance, as shown in the meta-analyses by Orlitzky et al. (2003) and Margolis et al. (2009). Margolis et al. for instance analyse 251 studies and find that the overall effect is positive but small, with results for the 106 studies from the previous decade being even smaller. They also review the many contingencies examined in the literature as potential moderators of the relationship and conclude that none of them markedly affects the results, with the exception of the negative effect of revealed misdeeds on financial performance.

Eccles et al.'s (2014) more recent review paints an even more mixed picture, with findings of positive, negative, U-shaped, and inverted-U-shaped relations between CSR and financial performance. As they note, however, most studies fail to measure financial performance over long enough periods of time to allow for CSR practices to have an impact on financial performance. This is important because some CSR studies argue that firms investing in CSR create shareholder value in the long run, but stock markets undervalue CSR in the short run (Renneboog et al. 2008).

In contrast, Eccles et al. track the performance of their sample firms over eighteen years (1993 to 2010) and find that high-sustainability companies outperform lowsustainability companies in both accounting profitability and stock returns. Khan et al. (2016) find that the materiality of different sustainability issues, which varies systematically across firms and industries, plays a critical role in the relation. Namely, firms with good CSR ratings significantly outperform firms with poor ratings, but only on issues that are material for those firms or their industries.

Lins et al. (2017) report that, during the 2008-9 financial crisis, high-CSR firms had higher stock returns, profitability, growth, and sales per employee relative to lowCSR firms, and raised more debt. The implication is that the trust built by firms through investments in social capital becomes particularly valuable when the overall level of trust in corporations and markets suffers a negative shock. 
Despite the promising results of these last studies, the sheer perception of a tradeoff between financial and non-financial performance may be enough to deter many investors from engaging in, let alone driving, sustainable business practices. Moreover, although such practices may require sacrifices or concessions from stakeholders other than (or not just from) shareholders, the latter are often seen as the ultimate cost bearers. For instance, several articles denounce managerial engagement in responsible business practices as a form of agency behaviour, such that managers enhance their personal reputation at the expense of shareholders (Barnea \& Rubin 2010, Cheng et al. 2013, Masulis \& Reza 2015). A related agency argument is that managers may engage in CSR practices to reduce conflict with stakeholders, at a financial cost to shareholders (Jensen 2001). Along the same lines, Cespa and Cestone (2007) argue that, when stakeholder protection is left to the voluntary initiative of managers, relations with social activists may become an effective entrenchment strategy for inefficient CEOs.

On the other hand, Ferrell et al. (2016) find that well-governed firms that suffer less from agency concerns engage more in CSR and that CSR is positively related to firm value. Likewise, Harjoto and Jo (2011) find that firms use CSR engagement to reduce conflicts of interest between managers and non-investing stakeholders, but that CSR engagement positively influences operating performance and firm value, and thus comes at a net benefit rather than a cost to shareholders.

Finally, although research about the relation between social and financial performance has used a variety of sources to measure social and environmental performance, no research to date has examined the relation between financial returns to shareholders and taxes paid as a form of social contribution, nor the trade-off that may exist between taxes paid and direct investments in CSR practices.

\section{HOW DO OWNERS BUILD SUSTAINABLE AND RESPONSIBLE BUSINESS?}

\section{How different owners can drive responsible business practices}

There is a broad range of ways in which for-profit companies can create shared value for a broad range of stakeholders: from incorporating CSR practices to their existing strategy to having a social purpose embedded in their business model by design since the company's inception. In between lie various forms of organisational change that range from the purely incremental to more radical business model transformations. It is important to recognise this variety of existing approaches to responsible business because there is likely to be a mutual dependency between it and business ownership. Where a firm lies within this range of approaches is typically in no small part a 
consequence of who owns the firm, or has owned it in the past, but the role that owners can be expected to play in the future in building responsible and sustainable businesses in turn greatly depends on where businesses are in this continuum.

For instance, if we take 'B corps' (companies certified by the non-profit B Lab to meet rigorous standards of social and environmental performance, accountability, and transparency) as representative of the far end of the spectrum, their owners seem to have played a critical role in achieving those rigorous standards of social responsibility: of more than 2,100 B corps around the world, only five are or have been listed on major exchanges thus far: three in the US (Etsy and Laureate Education; Rally Software was acquired in 2015), one in Brazil (Natura), and one in Australia (Silver Chef). Moreover, with the exception of four cooperatives (Amicus Solar, Clean Energy Credit Union, and employee-owned PV squared and Namasté Solar), all other B corps remain under the control of their founders or founders' families. Other cooperatives more generally (not just those certified as B corps) are also in this category and represent a significant fraction of economic activity around the world, especially in certain developing countries (SEUK 2017). For instance, in Kenya they account for 45 per cent of GDP, more than either the public or private sector (British Council \& SEUK 2015).

Which of these founding owner types - shareholders versus cooperative members - are more effective at building responsible businesses from scratch is an open question, but they are clearly the main group driving social value creation. It is also not clear if what matters more is the owners themselves or the organisational formfor example, corporation versus partnership versus cooperative - since to some extent, the role of owners is defined by the organisational form. ${ }^{5}$ However, it is important to recognise that the organisational form is a choice of the founders or even subsequent owners (who may change it). But to the extent that certain organisational forms may be more effective than others at creating social value, it would be important to know it so that owners can make a more informed choice in this regard.

At the other end of the spectrum-publicly listed firms whose strategy is geared toward maximising profits or shareholder value - there is a greater diversity of owner types (families or institutional and retail investors, among others) and of roles that these owners can play in perpetuating or transforming these firms' traditional strategies. Institutional investors in particular can take a variety of approaches toward these firms that range from more passive to more active (Clark \& Viehs 2004). The most passive approach is the traditional negative screening — excluding 'sin stocks' in

\footnotetext{
${ }^{5}$ For instance, Acharya et al. (2008) show that directors who serve on boards of both public and private firms play a very different role, depending on which type of firm it is, on important governance functions, such as strategy formulation, management development and succession, performance monitoring, risk management, and stakeholder relations.
} 
businesses like alcohol, tobacco, gambling, or weapons - from investment portfolios. Next comes positive screening - ranking firms according to their performance on particular ESG criteria and selecting for investment only the highest ranked firms, sometimes in combination with shorting the lowest ranked ones.

The most active approach - and arguably the only one that deserves the label of 'impact investing' - is for institutions to engage directly with the board and management of corporations to encourage them to adopt more sustainable and responsible business practices. They can do this in several ways: by putting forward shareholder proposals related to ESG issues, by voting in favour of such proposals at annual general meetings, and/or by engaging in actual dialogue with the board or management. Brest et al. (2018) reserve the term 'social value creation' for this type of socially responsible investment, as opposed to the more passive forms, which they describe as simple 'value alignment'. This active approach has been reportedly growing fast not just among self-identified socially responsible investors but also among mainstream investors (Gifford 2010). As of 2018, the United-Nations-backed Principles for Responsible Investment (PRI), which contain commitments to active ownership on ESG issues, had over 1,800 signatories, ranging from very small organisations to some of the largest pension funds and fund managers in the world, and representing more than $\$ 80$ trillion in assets under management (PRI 2016). Most of these signatories engage in dialogue with investee companies to some extent to influence corporate behaviour.

The specific type of institutional investor-bank, insurance company, pension fund, mutual fund asset manager, hedge fund, endowment, foundation, family office, or sovereign wealth fund - is likely to play a defining role in the likelihood, approach, and success of their contribution to building sustainable and responsible businesses, for several reasons. One is the investment horizon, which in turn depends on who the ultimate owners or beneficiaries are (for instance, pension funds need to match their assets to their long-term liabilities; family offices seek to preserve their owning families' wealth for future generations, etc.). Serafeim (2015), for instance, shows that companies that produce integrated reports show a clear tendency to have more long-term, 'dedicated' institutional shareholders and fewer transient investors.

A second reason is that certain social and environmental issues need to be addressed through cooperation across competitors within a given industry; otherwise individual companies' socially responsible business behaviour may simply result in a transfer of financial value from those companies to less responsible businesses rather than in net social value creation. Examples of such issues, which are widespread, are overfishing, deforestation, pollution, water consumption, bribery, and obesity. Serafeim (2018) identifies two investor characteristics that can effectively shift the level of engagement from the individual company to the industry as a whole: 
common ownership (of competing firms by the same investors) and (again) long-term horizons. Three types of investors satisfy both criteria: (1) large index fund asset managers, such as Blackrock, State Street and Vanguard; (2) large active investors that effectively become quasi-indexers, such as Fidelity, JPMorgan, BNY Mellon, or Northern Trust; and (3) large pension funds such as Norges Bank Investment Management, the Swedish AP funds, CalPERS, and New York Common Retirement Fund. As Serafeim documents, large index and quasi-index investors have now built teams that engage with companies in their portfolios while large asset owners have been among the leaders in engaging with companies on environmental and social issues. Serafeim's (2018) findings can likely be extended to collaboration across industries (and not just within industries), whenever the solution to social and environmental issues may require such collaboration.

A third reason why institutional investor type matters to the likelihood of, approach to, and success at doing business responsibly is because different investor types have different cost structures. As Brest et al. (2018) point out, socially responsible investment - even in its least active forms - introduces an additional layer of asset management costs that may be difficult to cover by the low asset management fees of more passive investors like index funds.

The combination of these three and possibly other reasons suggests that their net effect on the relation between institutional investor type and CSR is an empirical question. As will be reviewed in the next section, some inroads have been made along these lines, but there is much room for further research.

\section{The roles of shareholders and other stakeholders in building sustainable and responsible businesses}

In addition to the collaboration across shareholders of competing firms discussed above for social and environmental issues that require industry-wide concerted action, building sustainable and responsible businesses typically requires collaboration among (a) different shareholders within the same firm, and (b) multiple stakeholder groups. Several studies of shareholder activism suggest that collaboration among shareholders increases the likelihood of success of activist engagements (Gillan \&Starks 2007, McCahery et al. 2016). Dimson et al. (2017) argue that both types of collaboration, which they label as 'hard' (across shareholders) and 'soft' (between shareholders and other stakeholders), are particularly critical to the success of engagements on social and environmental issues.

It remains an open question whether shareholders or any other stakeholder groups - employees, customers, suppliers, local communities, the government, or proxy advisors in public companies - are most effective at initiating a transformation 
of the entire ecosystem. For instance, customers may drive companies' responsible behaviour, either by rewarding such behaviours (paying a premium for responsibly made products or services) or by punishing irresponsible business practices (making CSR a selection (or retention) criterion). Consistent with this notion, Servaes and Tamayo (2013) find that CSR and firm value are positively related for firms with high customer awareness, but not otherwise. Presumably suppliers can also encourage or discourage responsible behaviour by their client companies in similar ways. Dai et al. (2018) analyse customer-supplier relationships from fifty countries worldwide and find that customers' CSR ratings are associated with suppliers' subsequent CSR performance, but not vice versa.

Dorobantu's work (Dorobantu \& Odziemkowska 2017, Dorobantu et al. 2017, Henisz et al. 2014) shows how communities can drive more sustainable and responsible business practices through their influence on corporate reputation and its repercussions on shareholder value.

Another channel through which sustainable business practices may propagate throughout an entire ecosystem is sheer competition among peer firms. Namely, if CSR creates a competitive advantage (for instance, reputational), when one company engages in responsible business practices, its competitors may follow suit. Consistent with this idea, Cao et al. (2018) find evidence of significant peer effects in CSR. Using a regression discontinuity design based on CSR shareholder proposals that pass or fail by a small margin of votes, they find that peers of firms that pass such proposals experience lower announcement returns and higher CSR scores in the following year than peers of firms that marginally reject similar proposals.

Employees can also initiate responsible behaviour in their companies in a bottom-up way. Using data from the ' 100 Best Companies to Work for in America', Edmans (2011) shows that employee satisfaction is positively correlated with shareholder returns. Gartenberg et al. (2018) use a survey of worker perceptions about their employers to construct measures of corporate purpose and find that high-purpose firms that are characterised by high camaraderie between workers as well as high clarity from management have systematically higher future accounting and stock market performance. As the agency literature discussed above suggests, managers are often the ones to initiate CSR practices in their companies, regardless of whether their actions are found to benefit or harm shareholders.

Proxy advisors likely play an increasingly important role in driving socially responsible behaviour amongst publicly listed companies. McCahery et al. (2016) report that 60 per cent of the activist investors who replied to their survey use proxy advisors, and find their advice to be valuable despite the concerns about potential conflicts of interest that arise from the consulting services offered by these firms. Moreover, investors that use proxy advisors indicate that they engage with their 
portfolio companies's management more intensively, rather than substituting proxy advice for their own voice.

Owners, in addition to their direct influence on a company's strategy, may also play an indirect role in inducing the adoption of sustainable business practices through some of these channels. For instance, several studies going back to Moskowitz and Levering (1993) have reported that at least half of the 'Best Companies to Work for in America' are family firms.

Niehm et al. (2008) document the mutual influence between family owners and rural communities, in which family businesses often comprise the primary resident and economic base. They find that, in the small and rural markets of their sample, just three dimensions - commitment to the community, community support, and sense of community - account for 43 per cent of the variation in family business operators' CSR.

Cao et al. (2018), building on Freeman's (2018) finding that common ownership between customers and suppliers increases the longevity of their relationships as well as the innovative and financial cooperation between the firms, find that common ownership and common board membership in both the customer and supplier facilitate the propagation of CSR practices from customer to supplier. If common ownership between vertically related firms has an impact on their CSR behaviour, common ownership between horizontally related firms (that is, competitors) is also likely to matter, as argued by Serafeim (2018). However, despite a growing volume of research about common ownership across competitors and its impact on corporate conduct (see Schmalz (2018) for a review), no study to date has investigated the impact of such common ownership on CSR.

Deng et al. (2013) find that mergers by high-CSR acquirers take less time to complete and are less likely to fail than mergers by low-CSR acquirers. In a corporate world that is characterised by high merger activity, such that business survival is largely defined by an 'eat or be eaten' approach (Grullón et al. 2017), the implication is that acquisitions may be an important channel for the propagation of sustainable business practices. Moreover, Matvos and Ostrovsky's (2008) finding - that institutional shareholders of acquiring firms often more than offset their losses as acquirors with their gains as shareholders of target firms in the same deals-suggests that common ownership and mergers can be mutually reinforcing mechanisms through which owners can drive the propagation of CSR practices across firms.

The efficacy of these various channels at building responsible and sustainable businesses is likely to vary geographically, although more research is needed to determine how. Dai et al. (2018) report that their overall finding that customers drive suppliers' CSR performance but not vice versa varies significantly across geographic locations. Using a sample of 23,000 companies from 114 countries, Liang and Renneboog (2017) find a strong correlation between firm's CSR ratings and their 
countries' legal origin. Specifically, they find that firms from common law countries have lower CSR ratings than companies from civil law countries, with Scandinavian civil law firms having the highest ratings. They also compare the explanatory power of legal origin to a range of firm and country characteristics, and conclude that legal origin is a stronger explanation than any of them. The firm characteristcs they consider include total ownership concentration and the ownership share held by different types of shareholders, including the government, corporations, pension funds, investment companies, employees, and foreign investors. With the exception of pension fund ownership, for which they find a negative sign, none of these variables is significantly related to CSR ratings. However, they do not investigate the interaction effects of ownership and legal origin, nor how the effects of ownership vary across countries.

\section{EMPIRICAL EVIDENCE ABOUT THE IMPACT OF OWNERSHIP ON CSR}

Most empirical studies have focussed on a specific owner type. In particular, families and institutional investors are the two corporate owner types that have received most attention. For instance, Musacchio et al. (2015) note that the impact of the various forms of state capitalism on social outcomes is a question that remains unexplored. Likewise, there is a dearth of research about the CSR behaviour of employee-owned businesses, despite the prevalence of this owner type in the service professions-law, accounting, investment banking, medicine - and other industries, as reported by Hansmann (1996). The social performance of cooperatives and other forms of social enterprise including hybrid social/commercial organisations (Battilana and Dorado 2017) has been the subject of much research; however, this research has largely proceeded without any overlap or explicit comparison to other forms of business organisation (Mayo 2011).

There are also very few studies that have compared the CSR performance of publicly listed and privately held firms and, despite reports about the increasing incorporation of ESG criteria into private equity investment (Barker et al. 2014), there is practically no academic research on the subject, with the exception of a few studies about the impact of private equity on employment. Among these are Amess and Wright $(2007,2012)$, who find that in the United Kindgdom there is no significant impact of private equity on employment overall but that the effect varies across management buyouts (which exhibit higher employment growth) and management buy-ins (where employment growth is lower). Davis et al. (2014) study the impact of private equity on employment using establishment-level data from the US Census. They find that establishments targetted by private equity investors exhibit a net 
employment contraction (large increases in gross job creation are more than offset by higher job destruction) and establishment exit.

There are, however, a few studies that have examined the impact of ownership concentration on CSR. Faller and zu Knyphausen-Aufseß (2018) cover many of these studies in their review of the theoretical and empirical literature on the relation between ownership and CSR. Their review indicates that this is a literature that has yielded very mixed results. Of the 149 studies that they review, 89 are empirical. Of these, 29 studies find a positive association between the ownership feature (for example, concentration) or type (for example, institutional or family) that they focus on and and CSR performance, 27 find a negative relation, and 23 find no association.

Moreover, most studies have focussed on a single dimension of ESG performance (typically environmental). For instance, Berrone et al. (2010) show that controlling families adopt environment-friendly strategies more frequently than non-family firms in polluting industries. Kim and Lyon (2011) study the impact on share prices of participating in the Carbon Disclosure Project (CDP), a consortium of institutional investors with $\$ 57$ trillion in assets. They find that CDP participation increased shareholder value only when the likelihood of climate change regulation rose due to Russia's ratification of the Kyoto Protocol, which caused the Protocol to go into effect. Among the few studies that examine the sustainability impact of state capitalism, Calza et al. (2016) and Hsu et al. (2017) show that firms with greater state ownership are more environmentally proactive and also more responsive to salient environmental events. Hsu et al. find the effect to be more pronounced in energy firms from emerging economies and countries with higher energy risks, and with direct shareholdings by domestic government, rather than sovereign wealth funds.

Nevertheless, a few studies have compared the impact of different owner types and/or focussed on multiple ESG dimensions. Because these studies are not covered by Faller and zu Knyphausen-Aufseß (2018), I review them here in slightly more detail. I also review some of the studies about family ownership or institutional ownership, given their relative importance within this literature, but refer to Faller and zu Knyphausen-Aufseß's paper for a more comprehensive review of those.

\section{Studies of different owner types and multiple CSR dimensions}

Using a 1993 cross-section of 252 public US corporations and KLD data, Johnson and Greening (1999) examine the impact of different institutional investor types as well as top management's equity holdings on two different dimensions of corporate social performance - a people-related measure that comprises women and minorities, community, and employee relations, and a product-related measure (product and environment). They find that pension funds have a positive impact on both measures 
and top management has a positive impact on the people measure. However, neither mutual funds nor investment bank funds have a significant relation with either.

On a 2005 cross-section of 600 European firms from 16 countries and 35 industries for 2005, Dam and Scholtens (2012) find that employees, individuals, and other corporations as owners are negatively associated with the social performance of the firms they invest in. In contrast, banks, institutional investors, and the state appear to be neutral in this respect. They also show that it is important to account for the multidimensional nature of CSR.

Rees and Rodionova (2013) provide further evidence that the impact of ownership on ESG depends on both the type of owner and the type of ESG. Using a large sample of 3,541 firms from thirty countries during the period 2002-10, they examine the impact of strategic or closely held shareholdings on different ESG elements, as reported by ASSET4. They find that total strategic or closely held equity holdings adversely affect all three aggregate scores, an effect that is largely driven by undiversified owners-families and other corporations. Conversely, government holdings impact environmental and social (but not governance) scores positively, as do institutional investors on governance (but not on the environmental or social dimensions, on which they have no significant effect).

Their more detailed analysis of fifteen sub-scores or themes underlying the three aggregate ESG scores shows that families and corporations as owners have a stronger negative impact on ESG themes that relate to benefits that fall outside the firm (such as business ethics, climate change, environmental management, and human rights) than on those that have an impact on the firm itself, such as internal governance, product development, health and safety, employment quality, and training and development.

Block and Wagner (2014) investigate the effect of ownership and management by founders and families (separately) on five CSR dimensions using a sample of 286 publicly listed US firms during the period 2003-13 and KLD data. They find that family ownership is negatively associated with community-related CSR performance and positively associated with aspects related to diversity, employee relations, environment, and product. They find very similar results for founder ownership (which they analyse separately) except for employee relations, as well as for family CEOs. However, founder CEOs have opposite sign-effects to founder and family ownership on almost all CSR dimensions except for the environment.

Their regression models also include three other owner types: mutual funds, banks and insurance companies, and employee stock ownership plans (ESOPs). Although they do not discuss these results, their Table II shows that three categories have positive effects on community relations and the environment, and negative effects on diversity. Both categories of financial institutions have negative effects on employee relations 
(on which the effect of employee ownership is positive, not surprisingly). Mutual funds have a positive effect on product-related CSR performance while the other two groups have a negative effect. The statistical significance of these results varies widely, however; the authors use Bayesian regressions methods, which allow them to state the exact probability for each of these effects, but they do not report conventional significance levels, which makes their results difficult to compare with those in other studies.

As noted before, although there is a large literature on cooperatives and social enterprises, there is a dearth of research comparing their social performance to other organisational forms such as private-sector corporations or even state-owned enterprises. Part of the reason may be that equity represents a very small fraction (3-5 per cent) of the financing means of social enterprises (SEUK 2017). It is an open question whether the capital structure of these entities may or should change as the interest in socially responsible investment increases. For instance, Brown (2006) analyses the benefits and challenges of equity finance for social enterprises and concludes that there is significant scope for these entities to raise permanent capital from ethical investors.

\section{Family ownership and CSR performance}

There are as many theoretical arguments about why family ownership, control, or management may have a positive relation with social and environmental performance as there are to suggest a negative relation. Most salient among the former is families' longer term orientation relative to other owner types, which may manifest itself in higher tolerance to short-term losses (and/or greater insulation from capital market short-termistic pressures), as well as in longer lived relationships with a variety of stakeholders, including employees, customers, and suppliers. Families' desire to preserve the founder's legacy and reputation (part of their socio-emotional wealth stock) may also lead to more altruistic behaviour. On the other hand, the same desire to protect socio-emotional wealth and the insulation from capital market pressures may lead to more selfish behaviour on the part of family owners, who can appropriate 'private benefits of control' from other stakeholders, including public shareholders when they exist.

Moreover, it is important to recognise that business families have other channels beyond their operating business to do good, including foundations, and family office investments. A rigorous analysis of business families' contribution to society would therefore require a holistic view of the variety of channels through which they operate. No study to date has undertaken such an endeavour.

Faller and zu Knyphausen-Aufseß (2018) provide the most comprehensive review to date of academic research on this question. Perhaps not surprisingly given the 
theoretical ambiguity about it, empirical studies of this relation have also yielded mixed results. Out of nineteen studies that have examined it, twelve find a positive relation while four find a negative one, and three find no significant relation at all. I summarise here the most important studies reviewed by Faller and zu KnyphausenAufse $B$ as well as others that their review does not cover.

Using a sample of 261 S\&P500 firms during the period 1991-2000, Dyer and Whetten (2006) find no significant difference between family and non-family firms in KLD's seven 'positive initiatives'. However, they also find that family firms generate significantly fewer social concerns (that is, are more socially responsible) regarding products, employees, and the environment. They attribute these findings to families' desire to protect their image, reputation, and family assets. Butler and Roundy (2017) find similar results on a more recent sample of seventy Fortune 500 firms over the period 1994-2006. They find that family firms display fewer environment- and employeerelated CSR concerns, but more diversity-related CSR concerns. On the other hand, Bingham et al. (2011) show exactly the opposite findings to Dyer and Whetten's.

On a panel of 598 European listed firms between 2008 and 2012, Cruz et al. (2014) find almost opposite results to those of Rees and Rodionova (2013), different also from those of Block and Wagner (2014) (both described above). Namely, they find that family firms have a positive effect on social dimensions linked to external stakeholders, yet have a negative impact on internal social dimensions. They attribute their findings to families' desire to protect their socio-emotional wealth. They also find that national standards and industry conditions influence the degree of CSR in non-family firms, but do not affect family firms. However, family firms' social activities are more sensitive to declining organisational performance.

Rees and Rodionova (2015), using a sample of 3,893 firms from 46 different countries during the period 2002-12 and ASSET4 ESG rankings, find that closely held equity in general and family ownership in particular are both negatively associated with ESG performance on all three dimensions. They interpret these findings as evidence that families are guided by personal benefits and have lower reputational pressure to undertake social and environmentally responsible investments. The strength and consistency of their results are greater in liberal market economies than in coordinated market economies.

In light of these mixed results (when not contradictory altogether), some researchers have focussed their attention on explaining the heterogeneity across family firms in their approach toward CSR (e.g., Déniz \& Cabrera Suárez 2005, Marques et al. 2014). While there is value to this type of study, it essentially bypasses the issue of whether and why certain owner types may be better suited to direct their firms to behave responsibly. 


\section{Institutional investors and CSR performance}

As described by Sparkes and Cowton (2004), socially responsible investment (SRI) has evolved from the domain of a small number of specialist retail investment funds into the mainstream by a growing proportion of large institutional investors. A number of studies have examined the likelihood and/or success of one or more of the three approaches to CSR by institutional investors described above - negative and positive screening, and direct engagement.

Almost by definition, negative screening leads to an improvement in the CSR performance of the investment portfolios that follow this approach, but does not change the behaviour of the underlying investee firms. Moreover, as Hong and Kacperczyk (2009) show, the neglect of sin stocks by many institutional investors drives up the expected rates of return on those stocks and may thus have the undesirable effect of perpetuating socially irresponsible business practices.

Most research on positive screening has focussed on the risk and return implications of this approach for investors and generated inconclusive results about whether environmental and social performance is positively or negatively correlated with financial performance (see, for example, Renneboog et al. (2008) or Clark and Viehs (2014) for reviews of this literature). Although a positive relation should encourage further investing into socially responsible business, there is no empirical research directly addressing the question of whether this form of SRI has an impact on firm behaviour.

A few studies have looked at active ownership by institutions seeking to address environmental or social concerns. Several studies focus on the likelihood of these engagements. For instance, Sullivan and Mackenzie (2008) find that European investors are reluctant to intervene in situations where there is no compelling case for companies to improve their environmental or social performance and, by extension, no financial reason to do so. In a more recent survey, McCahery et al. (2016) report two additional impediments to shareholder activism: the threat of freerider behaviours, and legal concerns over 'acting in concert' rules. Nevertheless, they find that institutional investors are eager to adopt certain engagement means in order to influence responsible corporate behaviour. Specifically, 63 per cent of their 143 respondents state that in the past five years they have engaged in direct discussions with management, and 45 per cent state that they have had private discussions with a company's board outside of management's presence. They also find that the investment horizon makes a difference, with long-term investors intervening more intensively than shortterm ones.

Eding and Scholtens (2017) examine a sample of US Fortune 250 firms during the period 2011-14 and find that the probability of receiving shareholder proposals on 
environmental issues is positively associated with responsible institutional ownership. However, they find no evidence that the social performance of the firms themselves has a significant impact on this probability, except for employee well-being. Lafarre and van der Elst (2018) study shareholder activism at the annual shareholder meetings (AGMs) of Dutch listed companies and find that, despite a significant increase in institutional investors' interest in sustainability matters, their use of the forum right in AGMs is still low. As Becht et al.'s (2009) clinical study of the activist Hermes fund in the UK suggests, certain investors may predominantly execute their activism through private interventions that would be unobservable in studies relying purely on public information.

Other studies have looked into the effect of institutional shareholder engagements on corporate social behaviour. Thomas and Cotter (2007) report that none of the 403 social and environmental shareholder proposals in their sample garnered shareholder approval and that, consequently, very few were implemented by management. In contrast, Bauer et al. (2013) investigate the engagement activities of a large UK-based institutional investor in a global sample of target firms and conclude that they were relatively successful. Rehbein et al. (2013) examine corporate responses to activist shareholder groups filing social policy shareholder resolutions and find that management is more likely to engage in dialogue with shareholder activists when the firm is larger, more responsive to stakeholders, the CEO is the board chair, and the firm has a relatively lower percentage of institutional investors. Dimson et al (2017) study the private engagement activities of a large institutional investor in US public companies from 1999 to 2009. They find that firms with inferior governance and socially responsible institutional investors are more likely to be engaged, and that engagements are more likely to succeed if the investee firm has reputational concerns and higher capacity to implement changes, and when there is collaboration among investors or between them and other stakeholders. Successful engagements generate positive abnormal returns for investors and improved accounting performance for their firms, while unsuccessful engagements have no significant performance impact.

Dyck et al. (2018) examine whether institutional investors drive their firms' environmental and social performance in forty-one countries and find that they do, especially when those investors come from countries where environmental and social issues are important. Their results thus suggest that institutional investors can be a useful mechanism for spreading responsible business practices across countries. 


\section{CONCLUSIONS AND RECOMMENDATIONS FOR FUTURE RESEARCH}

This article reviews a large body of research that cuts across multiple fields of study to identify what we know and do not know about this subject. My review suggests that equity owners play a critical role in building sustainable and responsible businesses, but many aspects of that role deserve further investigation. In particular, the following issues appear to be outstanding and seem particularly important in that more knowledge about them is required to inform recommendations for business practice or policy that are likely to be of greater impact in building more responsible and sustainable businesses.

1. Who is most effective at building sustainable and responsible businesses (which type of owner, stakeholder, or organisational form) and why?

There is much room for research about which individuals or organisations may be most effective at either building responsible businesses from scratch or at initiating the transformation of existing business models from more traditional to more socially responsible ones, and under what circumstances. The question remains open at multiple levels: Which stakeholder group - entrepreneurs, shareholders, employees, customers, suppliers, local communities, the government, etc.? Which type of ultimate owner-families, governments, employees, or institutional investors? Which organisational form that owners choose to do business through - for example, corporation versus partnership versus cooperative in the private sector, or state-owned enterprises versus sovereign wealth funds for government capital? Which type of institutional investor - index funds, pension funds, socially responsible investment funds, etc.?

2. Does the recent evolution of capital markets and its resulting structure (for example, with fewer public firms and more common ownership by the same institutional investors across firms that are horizontally or vertically related) make CSR behaviour more likely or more effective?

A necessary first step in order to understand the role of ownership in building sustainable businesses is to understand who owns corporations and other forms of business organisation and social enterprise around the world: what is the 'equity investment chain' (Kay 2012) between businesses and their ultimate owners; and who within the chain exercises different ownership rights?

Although there is a growing literature on corporate ownership and control, few studies have examined the evolution of ownership rigorously and over long periods time. (Exceptions include Wright et al. (1994), Kaplan and Strömberg (2009), and 
Franks and Mayer (2017), among others.) ${ }^{6}$ Fewer yet have paid attention to the fact noted above, that the number of public corporations in the United States and the United Kingdom has fallen dramatically over the past two decades. Although institutional investors in these markets are acutely aware of this phenomenon, academic researchers have only begun to notice it and investigate its causes and consequences for investors.

Moreover, there is very little research about the implications of this phenomenon on corporate behaviour and responsible behaviour in particular. For instance, it has been widely documented that the lower number of public firms has resulted in increased common ownership of firms in the same industry, raising anti-competitive concerns among scholars and regulators.

However, the questions of whether common ownership across firms that are horizontally or vertically related makes their socially responsible behaviour more likely or more effective remain unexplored and should be of interest to both academics and regulators. For instance, those concerned about the potential anti-competitive effects of common ownership across competitors should be wary of the negative social impact that deterring such common ownership may have. It would also be interesting to compare the effectiveness of common ownership to that of other, nonequity-based, forms of collaboration across investors, such as coordinated activism, following common advice by proxy advisors on certain issues, or affiliating with socially responsible investment organisations like Ceres or the PRI.

\section{What explains some of the mixed or inconsistent results found across studies of} family ownership and CSR?

There is a significant amount of research comparing the CSR performance of family firms against non-family firms. However, this research has yielded contradictory results, which suggests there is room for further research that may shed light on what explains the differences in results across studies. Such research may be warranted given that most companies around the world, including most public corporations, are controlled by founders or their families, and may have practical implications for entrepreneurs, family business owners, and regulators. For instance, raising or lowering succession taxes is likely to have an impact on socially responsible investments by

${ }^{6}$ Stamm and Lubinski's (2011) review of over a hundred academic studies on family business succession illustrates this lack of rigour. Twenty-eight studies in their sample mention the 'empirical fact' that only 30 per cent of family businesses survive into the second generation and even less than $10-15$ per cent make it to the third generation (references to these same statistics outside academic studies count themselves in the thousands). None of these twenty-eight academic studies substantiates these statistics with their own empirical analysis. Moreover, Stamm and Lubinski trace the listed references (when any) for the alleged survival rate of family businesses and find that they are only supported by one empirical study_John Ward's (1987) analysis of 200 regionally focussed manufacturing companies. 
family firms. Given the volume of research that already exists on the subject, however, further research on the topic should differentiate itself from most previous studies by using better data, longer time series, better research methodologies, or different research designs. For instance, one promising research avenue may be to focus on specific business decisions and compare them across a mixed sample of ownership structures. Examples include executive selection and compensation; plant location, openings, and closings; mergers; recapitalisations; and dividend policies.

\section{How do different owner types other than families and instutional investors perform on social and environmental dimensions?}

As noted above, most of the research about the CSR practices or ESG performance of certain owner types has focussed on families and/or institutional investors. Although the weight of this research is proportional to the prevalence of both owner types, it would be interesting to learn more about other types of owners that are also very prevalent, particularly in certain industries and economies, such as the state, industrial foundations (Thomsen 2017), and employees.

Publicly listed corporations with significant ownership from any of these groups offer a particularly promising avenue for future research, not just because of data availability but also because, by virtue of their being publicly held, they are most exposed to the rigours and prejudices of contemporary capital markets. At the same time, the goals of their controlling (or significant) owners are not purely financial but also socially oriented on at least some dimension, and can be seen as hybrid organisations. Thus, this is a context where the greatest tension between competitive advantage and non-wealth-maximising corporate behaviour exists.

\section{Acknowledgements}

I would like to thank Colin Mayer as well as Marco Becht, Scarlett Brown, Ronald Gilson, Conor Kehoe, Giovana Nicodano, David Petrie, Henry Richards, Malcolm Salter, Alexis Wegerich, Paula Woodman, Charles Worth, and other participants in the Future of the Corporation Programme Remote Roundtable Discussion, as well as two anonymous reviewers for their valuable comments and suggestions. 


\section{REFERENCES}

Acharya, V., Kehoe, C. \& Reyner, M. (2008), 'The Voice of Experience: Public Versus Private equity', The McKinsey Quarterly, December.

https://www.mckinsey.com/business-functions/strategy-and-corporate-finance/our-insights/thevoice-of-experience-public-versus-private-equity

Amess, K. \& Wright, M. (2007), 'The Wage and Employment Effects of Leveraged Buyouts in the UK', International Journal of the Economics of Business, 14: 179-195. https://doi.org/10.1080/13571510701343923

Amess, K. \& Wright, M. (2012), 'Leveraged Buyouts, Private Equity and Jobs', Small Business Economics, 38: 419-30. https://doi.org/10.1007/s11187-010-9280-9

Bacon, N. Wright, M., Ball, R. \& Meuleman, M. (2013), 'Private Equity, HRM, and Employment', Academy of Management Perspectives, 27: 7-21. https://doi.org/10.5465/amp.2012.0130

Barker, N., Beaton, S., Tyrrell, S., Allen, S. \& WSP (2014), 'Environmental and Social Governance in Investment and Transaction Decisions', paper 61, Institute of Chartered Accountants in England and Wales.

Barnea, A. \& Rubin, A., (2010), 'Corporate Social Responsibility as a Conflict Between Shareholders', Journal of Business Ethics, 97: 71-86. https://doi.org/10.1007/s10551-010-0496-z

Battilana, J. \& Dorado, S. (2017), 'Building Sustainable Hybrid Organizations: The Case of Commercial Microfinance Organizations', Academy of Management Journal, 53: 1419-40. https://doi.org/10.5465/amj.2010.57318391

Bauer, R., Clark, G. L. \& Viehs, M. (2013), 'The Geography of Shareholder Engagement: Evidence From A British Institutional Investor', ECCE working paper, Maastricht University and University of Oxford.

Becht, M., Franks, J., Mayer, C. \& Rossi, S. (2009), 'Returns to Shareholder Activism: Evidence from a Clinical Study of the Hermes UK Focus Fund', Review of Financial Studies, 22: 3093-129. https://doi.org/10.1093/rfs/hhn054

Berrone, P., Cruz, C., Gómez-Mejía, L. R. \& Larraza-Kintana, M. (2010), 'Socioemotional Wealth and Corporate Responses to Institutional Pressures: Do Family-controlled Firms Pollute Less?', Administrative Science Quarterly, 55: 82-113. https://doi.org/10.2189/asqu.2010.55.1.82

Bingham, J. B., Dyer, W. G., Smith, I. \& Adams, G. L. (2011), 'A Stakeholder Identity Orientation Approach to Corporate Social Performance in Family Firms', Journal of Business Ethics, 99: 565-85. https://doi.org/10.1007/s10551-010-0669-9

Block, J. H. \& Wagner, M. (2014), 'The Effect of Family Ownership on Different Dimensions of Corporate Social Responsibility: Evidence from Large US Firms', Business Strategy and the Environment, 23: 475-92. https://doi.org/10.1002/bse.1798

Brest, P., Gilson, R. J. \& Wolfson, M. A. (2018), 'How Investors Can (and Can't) Create Social Value', working paper 394, European Corporate Governance Institute.

British Council \& SEUK (Social Enterprise UK) (2015), 'Think Global, Trade Social. How Business With a Social Purpose Can Deliver More Sustainable Development'. https://www.britishcouncil. org/sites/default/files/seuk_british_council_think_global_report.pdf

Brown, J. (2006), 'Equity Finance for Social Enterprises', Social Enterprise Journal, 75: 73-81. https://doi.org/10.1108/17508610680000714

Bushee, B. (1998), 'The Influence of Institutional Investors on Myopic R\&D Investment Behaviour', The Accounting Review, 73: 305-33.

Bushee, B. (2004), 'Identifying and Attracting The 'Right' Investors: Evidence on the Behaviour of Institutional Investors', Journal of Applied Corporate Finance 26: 28-35. https://doi.org/10.1111/j.1745-6622.2004.tb00671.x 
Butler, F. C. \& Roundy, P. (2017), 'Family Firms and Corporate Social Responsibility: Exploring "Concerns"', Journal of Strategy and Management, 10: 469-87. https://doi.org/10.1108/JSMA-02-2016-0010

Calza, F., Profumo, G. \& Tutore, I. (2016), 'Corporate Ownership and Environmental Proactivity', Business Strategy and the Environment, 25: 369-89. https://doi.org/10.1002/bse.1873

Cao, J., Liang, H. \& Zhan, X. (2018), 'Peer Effects of Corporate Social Responsibility', Management Science (forthcoming).

Cespa, G. \& Cestone, G. (2007), 'Corporate Social Responsibility and Managerial Entrenchment', Journal of Economics and Management Strategy, 16: 741-71. https://doi.org/10.1111/j.1530-9134.2007.00156.x

Cheng, I-H., Hong, H. \& Shue, K. (2013), 'Do Managers Do Good With Other People's Money?', working paper 19432, National Bureau of Economic Research, Cambridge, MA.

Claessens, S., Djankov, S. \& Lang, L. H. P. (2000), 'The Separation of Ownership and Control in East Asian Corporations', Journal of Financial Economics, 58: 81-112. https://doi.org/10.1016/S0304-405X(00)00067-2

Clark, G. L. \& Viehs, M. (2014), 'The Implications of Corporate Social Responsibility for Investors. An Overview and Evaluation of The Existing CSR Literature', Investing Review.

Cruz, C., Larraza-Kintana, M., Garcés-Galdeano, L. \& Berrone, P. (2014), 'Are Family Firms Really More Socially Responsible?', Entrepreneurship Theory and Practice, 38: 1295-316. https://doi.org/10.1111/etap.12125

Dai, R., Liang, H. \& Ng, L. (2018), 'Socially Responsible Corporate Customers', working paper 560, European Corporate Governance Institute.

Dam, L. \& Scholtens, B. (2012), 'Does Ownership Type Matter for Corporate Social Responsibility?', Corporate Governance: An International Review, 20: 233-52. https://doi.org/10.1111/j.1467-8683.2011.00907.x

Davis, S. J., Haltiwanger, J., Handley, K., Jarmin, R., Lerner, J. \& Miranda, J. (2014), 'Private Equity, Jobs, and Productivity', American Economic Review, 104: 3956-90. https://doi.org/10.1257/aer.104.12.3956

Deng, X., Kang, J.-K. \& Low, B.S. (2013), 'Corporate Social Responsibility and Stakeholder Value Maximization: Evidence from Mergers', Journal of Financial Economics, 110: 87-109. https://doi.org/10.1016/j.jfineco.2013.04.014

Déniz, M. C. \& Cabrera Suárez, M. K. C. (2005), 'Corporate Social Responsibility and Family Business in Spain', Journal of Business Ethics, 56: 27-41. https://doi.org/10.1007/s10551-004-3237-3

Dimson, E., Karakas, O. \& Li, X. (2015), 'Active Ownership', Review of Financial Studies, 28: 3225-68. https://doi.org/10.1093/rfs/hhv044

Doidge, C. G., Karolyi, A. \& Stulz, R. (2017), 'The U.S. Listing Gap', Journal of Financial Economics, 123: 464-87. https://doi.org/10.1016/j.jfineco.2016.12.002

Dorobantu, D. \& Odziemkowska, K. (2017), 'Valuing Stakeholder Governance: Property Rights, Community Mobilization and Firm Value', Strategic Management Journal, 38: 2682-703. https://doi.org/10.1002/smj.2675

Dorobantu, S., Henisz, W. \& Nartey, L. (2017), 'Not All Parks Light a Fire: Stakeholder and Shareholder Reactions to Critical Events in Contested Markets', Administrative Science Quarterly, 62: 561-97. https://doi.org/10.1177/0001839216687743

Dyck, A., Lins, K., Roth, L. \& Wagner, H. (2018), 'Do Institutional Investors Drive Corporate Social Responsibility: International Evidence', Journal of Financial Economics, (forthcoming). https://doi.org/10.1016/j.jfineco.2018.08.013

Dyer, W. G. \& Whetten, D. A. (2006), 'Family Firms and Social Responsibility: Preliminary Evidence From the S\&P 500', Entrepreneurship Theory and Practice, 30: 785-802. https://doi.org/10.1111/j.1540-6520.2006.00151.x 
Eccles, R.G., Ioannou, I. \& Serafeim. G. (2014), 'The Impact of Corporate Sustainability on Organizational Processes and Performance', Management Science, 60: 2835-57. https://doi.org/10.1287/mnsc.2014.1984

Eding, E. \& Scholtens, B. (2017), 'Corporate Social Responsibility and Shareholder Proposals', Corporate Social Responsibility and Environmental Management, 24: 648-60. https://doi.org/10.1002/csr.1434

Edmans, A. (2011), 'Does the Stock Market Fully Value Intangibles? Employee Satisfaction and Equity Prices', Journal of Financial Economics, 101: 621-40. https://doi.org/10.1016/j.jfineco.2011.03.021

Engel, E., Hayes, R. M. \& Wang, X. (2007), 'The Sarbanes-Oxley Act and Firms' Going-private Decisions', Journal of Accounting and Economics, 44: 116-45. https://doi.org/10.1016/j.jacceco.2006.07.002

Faccio, M. \& Lang, L. H. P. (2002), 'The Ultimate Ownership of Western European Corporations', Journal of Financial Economics, 65: 365-95. https://doi.org/10.1016/S0304-405X(02)00146-0

Faller, C. M. \& zu Knyphausen-Aufseß, D. (2018), 'Does Equity Ownership Matter for Corporate Social Responsibility? A Literature Review of Theories and Recent Empirical Findings', Journal of Business Ethics, 150: 15-40. https://doi.org/10.1007/s10551-016-3122-x

Ferrell, A., Liang, H. \& Renneboog, L. (2016), 'Socially Responsible Firms', Journal of Financial Economics, 122: 585-606. https://doi.org/10.1016/j.jfineco.2015.12.003

Franks, J. \& Mayer, C. (2017), 'Evolution of Ownership and Control Around the World: The Changing Face of Capitalism', working paper 503, European Corporate Governance Institute.

Freeman, K. M. (2018), 'The Effects of Common Ownership on Customer-Supplier Relationships'. https://editorialexpress.com/cgi-bin/conference/download.cgi?db_name=AFA2018\&paper_id=338

Gao, X., Ritter, J. R. \& Zhu, Z. (2013), 'Where Have All the IPOs Gone?', Journal of Financial and Quantitative Analysis, 48: 1663-92. https://doi.org/10.1017/S0022109014000015

Gartenberg, C., Prat, A. \& Serafeim, G, (2018), 'Corporate Purpose and Financial Performance', working paper, Harvard Business School, Cambridge, MA.

Gifford, J. (2010), 'Effective Shareholder Engagement: The Factors That Contribute to Shareholder Salience', Journal of Business Ethics, 92: 79-97. https://doi.org/10.1007/s10551-010-0635-6

Gillan, S. \& Starks, L. (2007), 'The Evolution of Shareholder Activism in The United States', Journal of Applied Corporate Finance, 19: 55-73. https://doi.org/10.1111/j.1745-6622.2007.00125.x

Gómez-Mejía, L.R., Haynes, K.T., Núñez-Nickel, M., Jacobson, K. J. L. \& Moyano-Fuentes, J. (2007), 'Socioemotional Wealth and Business Risks in Family-Controlled Firms: Evidence from Spanish Olive Oil Mills', Administrative Science Quarterly, 52: 106-37. https://doi.org/10.2189/asqu.52.1.106

Grullón, G., Larkin, Y. \& Michaely, R. (2017), 'The Disappearance of Public Firms and the Changing Nature of U.S. Industries', working paper, Rice University, Houston, TX.

Hansmann, H. (1996), The Ownership of Enterprise (Cambridge, MA, Belknap Press).

Harjoto, M. A. \& Jo, H. (2011), 'Corporate Governance and CSR Nexus', Journal of Business Ethics, 100: 45-67. https://doi.org/10.1007/s10551-011-0772-6

Henisz, W., Dorobantu, S. \& Nartey, L. (2014), 'Spinning Gold: The Financial Returns to Stakeholder Engagement', Strategic Management Journal, 35: 1727-48. https://doi.org/10.1002/smj.2180

Holderness, C. (2009), 'The Myth of Diffuse Ownership in the United States', Review of Financial Studies, 22: 1377-408. https://doi.org/10.1093/rfs/hhm069

Hong, H. \& Kacperczyk, M. (2009), 'The Price of Sin: The Effects of Social Norms on Markets', Journal of Financial Economics, 93: 15-36. https://doi.org/10.1016/j.jfineco.2008.09.001

Hoskisson, R. E., Hitt, M.A., Johnson, R. A. \& Grossman, W. (2017), 'Conflicting Voices: The Effects of Institutional Ownership Heterogeneity and Internal Governance on Corporate Innovation Strategies', Academy of Manangement Journal, 45: 697-716. 
Hsu, P., Liang, H. \& Matos, P. (2017), 'Leviathan Inc. and Corporate Environmental Engagement', working paper, Singapore Management University.

Jensen, M. (2001), 'Value Maximization, Stakeholder Theory, and the Corporate Objective Function', Journal of Applied Corporate Finance, 14: 8-21. https://doi.org/10.1111/j.1745-6622.2001.tb00434.x

Johnson, R. A. \& Greening, D. W. (1999), 'The Effects of Corporate Governance and Institutional Ownership Types on Corporate Social Performance', Academy of Management Journal, 42: 564-76.

Kahan, M. \& Rock, E. (2010), 'Embattled CEOs', Texas Law Review, 88: 987-1051.

Kaplan, S. N. \& Strömberg, P. (2009.), 'Leveraged Buyouts and Private Equity', The Journal of Economic Perspectives, 23: 121-46. https://doi.org/10.1257/jep.23.1.121

Kay, J. (2012), 'The Kay Review of UK Equity Markets and Long-term Decision making'. https://assets. publishing.service.gov.uk/government/uploads/system/uploads/attachment_data/file/253454/bis12-917-kay-review-of-equity-markets-final-report.pdf

Khan, A., Serafeim, G. \& Yoon, M. (2016), 'Corporate Sustainability: First Evidence on Materiality', The Accounting Review, 91: 1697-724. https://doi.org/10.2308/accr-51383

Kim, E. H. \& Lyon, T. (2011), 'When Does Institutional Investor Activism Pay? The Carbon Disclosure Project', The B.E. Journal of Economic Analysis and Policy, 11, article 50. https://doi.org/10.2202/1935-1682.2676

La Porta, R., Lopez-de-Silanes, F. \& Shleifer, A. (1999), 'Corporate Ownership Around the World', Journal of Finance, 54: 471-517. https://doi.org/10.1111/0022-1082.00115

Lafarre, A. \& van der Elst, C. (2018), 'Shareholder Sustainability Activism in the Netherlands', working paper 396, European Corporate Governance Institute.

Liang, H. \& Renneboog, L. (2017), 'On the Foundations of Corporate Social Responsibility', Journal of Finance, 72: 853-909. https://doi.org/10.1111/jofi.12487

Lins, K. V., Servaes, H. \& Tamayo, A. (2017), 'Social Capital, Trust, and Firm Performance: The Value of Corporate Social Responsibility During the Financial Crisis', Journal of Finance, 72: 1785824. https://doi.org/10.1111/jofi.12505

Margolis, J. D., Elfenbein, H. A. \& Walsh, J. P. (2009), 'Does It Pay to Be Good ... And Does It Matter? A Meta-analysis of the Relationship Between Corporate Social and Financial Performance', working paper, Harvard University, Cambridge, MA.

Marques, P., Presas, P. \& Simon, A. (2014), 'The Heterogeneity of Family Firms in CSR Engagement: The Role of Values', Family Business Review, 27: 206-27. https://doi.org/10.1177/0894486514539004

Masulis, R. W. \& Reza, S. W. (2015), 'Agency Problems of Corporate Philanthropy', Review of Financial Studies, 28: 592-636. https://doi.org/10.1093/rfs/hhu082

Matvos, G. \& Ostrovsky, M. (2008), 'Cross-ownership, Returns, and Voting in Mergers', Journal of Financial Economics, 89: 391-403. https://doi.org/10.1016/j.jfineco.2007.11.004

Mayer, Colin (2013), Firm Commitment. Why the Corporation is Failing us and How to Restore Trust in It (Oxford, Oxford University Press).

Mayo, Ed (2011), 'Cooperative Performance', Sustainability Accounting, Management and Policy Journal, 2: 158-64. https://doi.org/10.1108/20408021111162182

McCahery, J. A., Sautner, Z. \& Starks, L. T. (2016), 'Behind the Scenes: The Corporate Governance Preferences of Institutional Investors', Journal of Finance, 71: 2905-32. https://doi.org/10.1111/jofi.12393

Miller, D., Wright, M., Le Breton-Miller, I. \& Scholes, L. (2015), 'Resources and Innovation in Family Businesses: The Janus-face of Socioemotional Preferences', California Management Review, 58: 20-40. https://doi.org/10.1525/cmr.2015.58.1.20 
Moskowitz, M. \& Levering, R. (1993), The 100 Best Companies to Work for in America (New York, Currency/Doubleday).

Musacchio, A., Lazzarini, S. \& Aguilera, R. (2015), 'New Varieties of State Capitalism: Strategic and Governance Implications', Academy of Management Perspectives, 19: 115-31. https://doi.org/10.5465/amp.2013.0094

Niehm, L. S., Swinney, J. \& Miller, N. J. (2008), 'Community Social Responsibility and Its Consequences for Family Business Performance', Journal of Small Business Management, 46: 331-50. https://doi.org/10.1111/j.1540-627X.2008.00247.x

Orlitzky, M., Schmidt, F. L. \& Rynes, S. L. (2003), 'Corporate Social and Financial Performance: A Meta-analysis', Organization Studies, 24: 403-41. https://doi.org/10.1177/0170840603024003910

PRI (2016), 'How Asset Owners Can Drive Responsible Investment: Beliefs, Strategies and Mandates', Principles for Responsible Investment. https://www.unpri.org/download?ac=1398

Rees, W. \& Rodionova, T. (2013), 'What Type of Controlling Investors Impact on Which Elements of Corporate Social Responsibility?', Journal of Sustainable Finance and Investment, 3: 238-263. https://doi.org/10.1080/20430795.2013.791143

Rees, W. \& Rodionova, T. (2015), 'The Influence of Family Ownership on Corporate Social Responsibility: An International Analysis of Publicly Listed Companies', Corporate Governance: An International Review, 23: 184-202. https://doi.org/10.1111/corg.12086

Rehbein, K., Logsdon, J. M. \& van Buren, H. J. (2013), 'Corporate Responses to Shareholder Activists: Considering the Dialogue Alternative', Journal of Business Ethics, 112: 137-54. https://doi.org/10.1007/s10551-012-1237-2

Renneboog, L., Ter-Horst, J. \& Zhang, C. (2008), 'Socially Responsible Investments: Institutional Aspects, Performance, and Investor Behaviour', Journal of Banking and Finance, 32: 1723-42. https://doi.org/10.1016/j.jbankfin.2007.12.039

Schmalz, M. C. (2018), 'Common-ownership Concentration and Corporate Conduct', Annual Review of Financial Economics, 10: 413-48. https://doi.org/10.1146/annurev-financial-110217-022747

Serafeim, G. (2015), 'Integrated Reporting and Investor Clientele', Journal of Applied Corporate Finance, 27: 34-51. https://doi.org/10.1111/jacf.12116

Serafeim, G. (2018), 'Investors as Stewards of the Commons?', Journal of Applied Corporate Finance, 30: 8-17. https://doi.org/10.1111/jacf.12294

Servaes, H. \& Tamayo, A. (2013), 'The Impact of Corporate Social Responsibility on Firm Value: The Role of Customer Awareness', Management Science, 59: 1045-61. https://doi.org/10.1287/mnsc.1120.1630

SEUK (2017), The Future of Business: State of Social Enterprise Survey Social Enterprise UK. https://www.socialenterprise.org.uk/Handlers/Download.ashx?IDMF=a1051b2c-21a4-461a896c-aca6701cc441

Sparkes, R. \& Cowton, C. J. (2004), 'The Maturing of Socially Responsible Investment: A Review of the Developing Link With Corporate Social Responsibility', Journal of Business Ethics, 52: 45-57. https://doi.org/10.1023/B:BUSI.0000033106.43260.99

Stamm, I. \& Lubinski, C. (2011), 'Crossroads of Family Business Research and Firm Demography-A Critical Assessment of Family Business Survival Rates', Journal of Family Business Strategy, 2: 117-27. https://doi.org/10.1016/j.jfbs.2011.07.002

Stout, L. A. (2007), 'The Mythical Benefits of Shareholder control', Virginia Law Review, 93: 798-809.

Stout, L. A. (2012), The Shareholder Value Myth: How Putting Shareholders First Harms Investors, Corporations, and the Public (San Francisco, CA, Berrett-Koehler).

Sullivan, R. \& Mackenzie, C. (2008), 'Can Investor Activism Play a Meaningful Role in Correcting Market Failures?', Journal of Corporate Citizenship, 31: 77-88.

Thomas, R. S. \& Cotter, J. F. (2007), 'Shareholder Proposals in the New Millennium: Shareholder Support, Board Response and Market Reaction', Journal of Corporate Finance, 13: 368-91. 
https://doi.org/10.1016/j.jcorpfin.2007.02.002

Thomsen, S. (2017), The Danish Industrial Foundations (Copenhagen, Djøf Publishing).

Villalonga, B. (2009), 'Growing, Financing, and Managing Family and Closely Held Firms: Overview of the Course', Harvard Business School, 209-137.

Villalonga, B. \& Amit, R. (2009), 'How Are U.S. Family Firms Controlled?', Review of Financial Studies, 22: 3047-91. https://doi.org/10.1093/rfs/hhn080

Ward, J. L. (1987), Keeping the Family Business Healthy. How to Plan for Continuing Growth, Profitability and Family Leadership (San Francisco, CA, Jossey-Bass).

Wright, M., Robbie, K., Thompson, S. \& Starkey, K. (1994), 'Longevity and the Life Cycle of MBOs', Strategic Management Journal, 15: 215-27. https://doi.org/10.1002/smj.4250150303

Note on the author: Belén Villalonga is a Professor of Management and Organisations and a Professor of Finance (by courtesy) at New York University's Stern School of Business. Between 2001 and 2012 she was a faculty member at Harvard Business School. Professor Villalonga's teaching, research, and advisory work is in the areas of corporate governance, strategy, and finance, with a special focus on family-controlled companies. Her award-winning research has been published in leading academic journals, has been cited over 10,000 times in scholarly articles, and has been featured in the leading international media outlets. She serves as an independent director at two publicly listed companies that are global leaders in their industries: Grifols (hemoderivatives) and Acciona (renewable energy and infrastructure), and previously at Talgo (high-speed trains). She also consults to business families around the world on family, ownership, and business matters.

To cite the article: Belén Villalonga (2018), 'The impact of ownership on building sustainable and responsible businesses', Journal of the British Academy, 6(s1): 375-403.

DOI https://doi.org/10.5871/jba/006s1.375

This article is licensed under a

Creative Commons Attribution-NonCommercial-NoDerivs 4.0 Unported License.

Journal of the British Academy (ISSN 2052-7217) is published by

The British Academy - the national academy for the humanities and social sciences.

10-11 Carlton House Terrace, London, SW1Y 5AH

www.britac.ac.uk 
